\title{
HUBUNGAN ANTARA TEMPAT PERINDUKAN NYAMUK AEDES AEGYPTI DENGAN KASUS DEMAM BERDARAH DENGUE DI KELURAHAN PENAJAM KECAMATAN PENAJAM KABUPATEN PENAJAM PASER UTARA
}

\author{
Sitti Badrah, Nurul Hidayah \\ Fakultas Kesehatan Masyarakat Universitas Mulawarman ${ }^{1)}$ \\ e-mail:sitti_badrah@yahoo.co.id
}

\begin{abstract}
Penajam Paser Utara Regency is a DHF endemic area with amount of DHF cases always high from 2005 and always rising every years. And penajam village is a village with the highest DHF cases in Penajam Paser Utara regency. With total DHF cases 21 or 32,79\% from total DHF cases on Penajam subdistrict. This research was observational comparative in the field with quantitative method and cross-sectional approach to 60 houses by observation and interview to respondents. The purpose of this research was to analyze the correlation of container, noncontainer, natural container and density figure of Aedes Aegypti mosquito larvae (DF) with Dengue Hemorrhagic Fever (DHF) cases. This research finds result that there are significant correlation between breeding place of Aedes Aegypti mosquito larvae such as type of container $(p=0.000)$, condition of container $(p=0.000)$, purity of container $(p=0.045)$, type of noncontainer $(p=0.000)$, type of natural container $(p=0.002)$ with the existence of the Aedes Aegypti mosquito larvae. While, density of Aedes Aegypti mosquito larvae did not have a significant correlation with the DHF cases $(p=1.000)$. It suggested that could be maximizing the $3 M$ Program and always making environment cleanliness to reduce DHF incidence in Penajam village area, Penajam Paser Utara regency.
\end{abstract}

Keywords : Mosquito Breeding Places, Container, Aedes Aegypti mosquito larvae, DHF cases.

\begin{abstract}
ABSTRAK
Kabupaten Penajam Paser Utara Merupakan Daerah Endemik penyakit DBD dengan jumlah kasus yang selalu tinggi sejak tahun 2005 dan selalu bertambah setiap tahun. Desa Penajam merupakan salah satu desa dengan jumlah kasus DBD tertinggi di Kabupaten Penajam Paser Utara dengan julah kasus 21 atau 32,79 \% total keseluruhan kasus DBD yang terjadi. Penelitian lapangan ini dilakukan secara komparatif observasional dengan metode kuantitatif dan pendekatan cross-sectional terhadap 60 rumah melaui observasi dan dan wawancara langsung ke responden. Tujuan dari penelitian ini adalah untuk menganalisis korelasi angka kontainer, nonkontainer, kontainer alami dan kepadatan larva nyamuk Aedes aegypti (DF) dari kasus Demam Berdarah Dengue (DBD). Hasil dari penelitian ini adalah ada korelasi yang signifikan antara tempat perkembangbiakan larva nyamuk Aedes aegypti seperti jenis kontainer $(p=0,000)$, kondisi kontainer $(\mathrm{p}=0,000)$, kemurnian kontainer $(\mathrm{p}=0,045)$, jenis non-kontainer $(\mathrm{p}=0,000)$, jenis kontainer alam $(p=0,002)$ dengan keberadaan jentik nyamuk Aedes aegypti. Sementara, kepadatan larva nyamuk Aedes aegypti tidak memiliki korelasi yang signifikan dengan kasus DBD $(\mathrm{p}=1.000)$. Dari Hasil tersebut disarankan untuk memaksimalkan Program 3M dan selalu
\end{abstract}


membuat kebersihan lingkungan untuk mengurangi kejadian DBD di wilayah desa Penajam, Kabupaten Penajam Paser Utara.

Kata Kunci : Tempat pembiakan nyamuk, Container, Larva nyamuk Aedes Aegypti, Kasus DBD.

\section{LATAR BELAKANG}

Penyakit Demam Berdarah Dengue (DBD) sudah menjadi masalah kesehatan masyarakat global [1]. Kasus penyakit ini di Indonesia cenderung meningkat sejak pertama kali ditemukan. Pada tahun 1994, kasus DBD menyebar di seluruh Provinsi di Indonesia dengan 12 Provinsi di antaranya terjadi KLB (Kejadian Luar Biasa) [2].

Survei dasar epidemiologi pem-berantasan DBD awal Pelita VI menunjukkan bahwa rata-rata House Index di Indonesia masih tinggi, yaitu sebesar 27\%. Angka ini masih jauh dari batas yang dapat ditoleransi yaitu $<5 \%$ [3].

Data di Dinas Kesehatan Provinsi Kalimantan Timur mencatat, angka kasus DBD setiap tahunnya selalu tinggi, dengan angka kematian yang tinggi pula. Pada tahun 2009 telah ditemukan 3.437 kasus dengan angka kematian mencapai 46 orang. Saat ini ABJ disejumlah daerah di Kalimantan Timur baru mencapai $64 \%$ sampai $80 \%$. Sementara nilai standar ABJ yaitu 95\%, sehingga penularan DBD akan terus berlangsung dan dikhawatirkan bisa meningkat dalam status KLB [4].

Sementara, di Penajam Paser Utara, penyakit Demam Berdarah sangat berfluktuasi selama beberapa tahun terakhir. Pada tahun 2005 tercatat 41 kasus DBD, dan Tahun 2006 berjumlah 66 kasus DBD, serta pada tahun 2007 meningkat menjadi 138 kasus DBD. Kemudian pada tahun 2008 mengalami penurunan menjadi 96 kasus DBD dan terjadi kembali peningkatan tajam pada tahun 2009 yaitu 178 kasus. Sementara sampai bulan juni 2010, telah tercatat 162 kasus baru [5].

Kecamatan penajam merupakan kecamatan dengan jumlah penderita DBD tertinggi yaitu 61 kasus atau hampir $40 \%$ dari seluruh jumlah penderita DBD di Kabupaten Penajam Paser Utara sampai pertengahan tahun 2010. Sementara Kelurahan Penajam menduduki peringkat pertama kejadian kasus DBD di kecamatan Penajam yaitu 32,79\% dari total kasus DBD kecamatan Penajam.

Hasil survey yang dilakukan P2M Puskesmas Penajam tahun 2007 terhadap tempat penampungan air pada 276 rumah, diperoleh hasil House Index (HI) sebesar 33,33\% dan Angka Bebas Jentik (ABJ) Kelurahan Penajam sebesar $66,67 \%$. Hal ini masih jauh dari standar yang ditetapkan oleh Depkes yaitu ABJ lebih dari 95\%. Rendahnya nilai ABJ dapat berpotensi meningkatkan penularan penyakit Demam Berdarah Dengue.

Berdasarkan hal tersebut, penelitian ini ditujukan untuk mengetahui hubungan tempat perindukan nyamuk Aedes Aegypti dengan kasus Demam Berdarah Dengue di kelurahan Penajam, kecamatan Penajam kabupaten Penajam Paser Utara.

\section{METODOLOGI PENELITIAN}

Jenis Penelitian yang digunakan adalah penelitian observasional komparatif di lapangan yang dilakukan dengan metode kuantitatif dengan pendekatan cross sectional.

Populasi dalam penelitian ini adalah semua rumah yang terletak di kelurahan Penajam 
yang dibagi menjadi dua, yaitu 3 RT di daerah studi (kasus DBD tinggi) di Kelurahan Penajam yaitu RT 01, RT 07 dan RT 22. Sedangkan 3 RT lainnya di daerah control (kasus DBD rendah) di Kelurahan Penajam yaitu RT 04, RT 11, dan RT 16. Sementara besar sampel masing-masing RT ditentukan dengan cara purposive sampling dengan mengambil 10 Rumah setiap RT sehingga keseluruhan sampel adalah 60 rumah.

Data didapatkan dengan metode wawancara, menggunakan kuesioner dan melakukan pengamatan langsung pada tempat perindukan vektor demam berdarah. Analisis data dengan menggunakan Chi-Square dan Fisher Exact.

\section{HASIL DAN PEMBAHASAN}

\section{Tempat Perindukan Nyamuk Aedes Aegypti}

Tempat Perindukan Nyamuk yang diteliti ada 3 macam yaitu Tempat Penampungan Air (TPA), Tempat Penampungan Air Lainnya (TPA Lainnya), serta Tempat Penampungan Air Alami (TPA Alami).

Dari 340 TPA yang diperiksa, jenis bahan TPA yang paling banyak terdapat jentik adalah yang terbuat dari semen (CI 86.7\%), kemudian besi (CI 45.7\%), tanah liat (CI $40.0 \%$ ), porselen (CI 9.5\%) dan pelastik (CI $7,4 \%)$.

Hal ini dapat terjadi karena bahan dari semen mudah berlumut, permukaannya kasar dan berpori-pori pada dindingnya. Permukaan kasar memiliki kesan sulit dibersihkan, mudah ditumbuhi lumut, dan mempunyai refleksi cahaya yang rendah. Refleksi cahaya yang rendah dan permukaan dinding yang berpori-pori mengakibatkan suhu dalam air menjadi rendah, sehingga jenis bahan TPA yang demikian akan disukai oleh nyamuk
Aedes Aegypti sebagai tempat perindukkannya. Hal ini sesuai dengan bionomik nyamuk Aedes aegypti yang senang pada kelembaban tinggi dan takut sinar (photopobia).

Bahan TPA dari porselen dan plastik mempunyai CI lebih rendah karena bahan ini tidak mudah berlumut, mempunyai permukaan yang halus dan licin serta tidak berpori sehingga lebih mudah untuk dibersihkan dibandingkan bahan dari semen, besi dan tanah liat.

Berdasarkan hasil uji statistic diperoleh nilai $\mathrm{P}$ value $=0.000(\mathrm{P}$ value $<0.05)$ maka dapat disimpulkan bahwa terdapat hubungan yang bermakna antara jenis TPA dengan keberadaan jentik. Hal ini sejalan dengan penelitian yang telah dilakukan oleh Nugroho [6] bahwa Keberadaan jenis TPA baik yang berada di dalam maupun di luar rumah responden mempunyai resiko yang tinggi sebagai tempat perindukan nyamuk Aedes aegypti.

Dari 340 jumlah TPA yang diperiksa, 207 (60.9\%) dalam keadaan terbuka, sedangkan yang tertutup sebanyak 133 (39.1\%). Dari 207 TPA yang dalam keadaan terbuka terdapat sebanyak $86(41.5 \%)$ positif jentik. Sementara terdapat $121(58.5 \%)$ TPA dalam keadaan terbuka, namun tidak terdapat jentik di dalamnya. Hal ini dapat terjadi karena responden membersihkan TPA secara rutin (1 minggu sekali) atau TPA berukuran kecil, sehingga air dalam TPA cepat habis dan tidak memungkinkan nyamuk Aedes betina untuk meletakkan telurnya di TPA tersebut. Sedangkan dari 133 TPA yang tertutup terdapat $1(0.8 \%)$ positif jentik. Hal ini dapat terjadi dikarenakan pada saat penelitian dilakukan TPA tersebut dalam keadaan tertutup, namun tidak tertutup kemungkinan apabila dalam penggunaan air sehari - hari, TPA ini dibiarkan dalam keadaan terbuka selama beberapa lama, sehingga 
memungkinkan nyamuk Aedes aegypti betina untuk meletakkan telurnya di TPA tersebut. Oleh sebab itu, dalam penggunaan air dianjurkan untuk sesegera mungkin menutup kembali TPA setelah digunakan. Hal ini dilakukan untuk meminimalisir kesempatan nyamuk Aedes aegypti betina dalam metetakkan telurnya pada TPA. Berdasarkan hasil uji statistic diperoleh nilai $P$ value $=0.000(P$ value $<0.05)$ maka dapat disimpulkan bahwa terdapat hubungan yang bermakna antara kondisi TPA dengan keberadaan jentik.

Tabel 1. Distribusi Keberadaan Jentik Aedes Aegypti berdasarkan Tempat Perindukan

\begin{tabular}{|c|c|c|c|c|c|c|}
\hline \multirow{3}{*}{ Tempat Perindukan } & \multicolumn{4}{|c|}{ Keberadaan Jentik } & \multirow{3}{*}{ Jumlah } & \multirow{3}{*}{$\mathrm{P}$ value } \\
\hline & \multicolumn{2}{|c|}{ Positif } & \multicolumn{2}{|c|}{ Negatif } & & \\
\hline & $\mathrm{N}$ & $\%$ & $\mathrm{n}$ & $\%$ & & \\
\hline \multicolumn{7}{|l|}{ 1. Jenis TPA } \\
\hline Semen & 26 & 86.7 & 4 & 13.3 & 30 & \multirow{6}{*}{0.000} \\
\hline Pelastik & 14 & 7.4 & 176 & 92.6 & 190 & \\
\hline Besi & 43 & 45.7 & 51 & 54.3 & 94 & \\
\hline Porselen & 2 & 9.5 & 19 & 90.5 & 21 & \\
\hline Tanah Liat & 2 & 40.0 & 3 & 60.0 & 5 & \\
\hline Jumlah & 87 & 25.6 & 253 & 74.4 & 340 & \\
\hline \multicolumn{7}{|l|}{ 2. Keberadaan Tutup TPA } \\
\hline Terbuka & 86 & 41.5 & 121 & 58.5 & 207 & \multirow[t]{3}{*}{0.000} \\
\hline Tertutup & 1 & 0.8 & 132 & 99.2 & 133 & \\
\hline Jumlah & 87 & 25.6 & 253 & 74.4 & 340 & \\
\hline \multicolumn{7}{|l|}{ 3. Kebersihan air pada TPA } \\
\hline Bersih & 87 & 26.6 & 240 & 73.4 & 327 & \multirow[t]{3}{*}{0.045} \\
\hline Tidak Bersih & 0 & 0 & 13 & 100 & 13 & \\
\hline Jumlah & 87 & 25.6 & 253 & 74.4 & 340 & \\
\hline \multicolumn{7}{|l|}{ 4.Jenis TPA Lainnya } \\
\hline Tempat Minum Hewan & 6 & 19.4 & 25 & 80.6 & 31 & \multirow{8}{*}{0.000} \\
\hline Kaleng Bekas & 9 & 13.8 & 56 & 86.2 & 65 & \\
\hline Botol & 4 & 8.7 & 42 & 91.3 & 46 & \\
\hline Pecahan Piring/ Gelas & 5 & 5.5 & 86 & 94.5 & 91 & \\
\hline Vas Bunga & 1 & 25 & 3 & 75 & 4 & \\
\hline Penampungan Kulkas & 0 & 0 & 48 & 100 & 48 & \\
\hline Pecahan Ember & 5 & 50 & 5 & 50 & 10 & \\
\hline Jumlah & 30 & 10.2 & 265 & 89.8 & 295 & \\
\hline \multicolumn{7}{|l|}{ 5. Jenis TPA Alami } \\
\hline Lubang di pohon & 6 & 26.1 & 17 & 73.9 & 23 & \multirow{6}{*}{0.002} \\
\hline Pelepah daun & 3 & 2.8 & 104 & 97.2 & 107 & \\
\hline Tempurung kelapa & 4 & 15.4 & 22 & 84.6 & 26 & \\
\hline Kulit Kerang & 0 & 0 & 9 & 100 & 9 & \\
\hline Potongan bamboo & 3 & 18.8 & 13 & 81.3 & 16 & \\
\hline Jumlah & 16 & 8.8 & 165 & 91.2 & 181 & \\
\hline
\end{tabular}

Hal ini sejalan dengan penelitian yang dilakukan Heldi [7] Tentang Kajian Tempat Perindukan Nyamuk Di Kabupaten Bantul Yogyakarta yang mendapatkan hasil bahwa keberadaan tutup pada kontener sangat mempengaruhi ada tidaknya jentik pada container tersebut.
Terdapat 327 (96.2\%) TPA dalam keadaan air bersih, sedangkan pada air yang tidak bersih sebanyak 13 (3.8\%). Dari 327 TPA yang dalam keadaan air bersih terdapat sebanyak $87(26.6 \%)$ TPA yang positif jentik, sedangkan dari 13 TPA yang tidak bersih terdapat $0(0 \%)$ TPA yang positif 
jentik. Berdasarkan data ini dapat dilihat bahwa keberadaan jentik Aedes Aegypti lebih banyak pada TPA dengan keadaan air bersih dibandingkan dengan TPA yang dalam keadaan air tidak bersih.

Berdasarkan hasil uji statistic diperoleh nilai $\mathrm{P}$ value $=0.045(\mathrm{P}$ value $<0.05)$ maka dapat disimpulkan bahwa terdapat hubungan yang bermakna antara kebersihan TPA dengan keberadaan jentik di kelurahan Penajam Kecamatan Penajam Tahun 2010.

Berdasarkan bionomik Nyamuk Aedes aegypti, nyamuk ini memang suka meletakkan telurnya pada air bersih dan tidak suka meletakkan telurnya pada air yang kotor/ keruh serta bersentuhan langsung dengan tanah. Tempat perindukan nyamuk Aedes aegypti sangat dekat dengan manusia yang menggunakan air bersih sebagai kebutuhan sehari-hari. Oleh sebab itu, sangat dibutuhkan menjaga kebersihan TPA yang digunakan, agar dapat meminimalisir perkembangan jentik nyamuk Aedes Aegypti pada air bersih di dalam TPA yang digunakan.

Kebersihan TPA berkaitan dengan kegiatan pengurasan yang dilakukan minimal seminggu sekali. Hal ini dianjurkan untuk memutus siklus kehidupan nyamuk dalam air (10 - 12 hari) agar tidak mencukupi waktu bagi jentik nyamuk untuk mencapai dewasa. Pengurasan dimaksud adalah membersihkan TPA dengan cara menyikat bak dan TPA yang lain dan mengganti air didalamnya dengan air yang bersih [8].

Sebagian besar penduduk Kelurahan Penajam memiliki banyak TPA dan sebagian TPA yang dimiliki diletakkan diluar rumah sebagai konteiner tadah hujan. Hal ini dilakukan karena keterbatasan sarana air bersih (PDAM) yang disuplay oleh pemerintah. Kurangnya air bersih ini membuat masyarakat kelurahan penajam jarang menguras TPA yang mereka miliki dengan alasan takut kehabisan persediaan air bersih.

Jenis wadah TPA Lainnya yang paling disukai nyamuk Aedes Aegypti sebagai tempat perindukan adalah pecahan ember 5 (CI 50\%), disusul vas bunga 1 (CI 25\%), tempat minum hewan 6 (19.4\%), kaleng bekas 9 (CI 13.8\%), botol bekas $4(8.7 \%)$ dan terakhir pecahan piring/ gelas $5(5.5 \%)$.

Hal ini dapat terjadi karena pecahan ember memiliki kapasitas menampung air yang lebih banyak, sehingga dapat menampung air dalam jangka waktu yang lebih lama. Pada saat penelitian dilakukan, curah hujan di Kelurahan Penajam relatif tinggi, sehingga TPA yang berukuran kecil tidak dapat menampung air dalam jangka waktu yang lama.

Sementara vas bunga memiliki CI terbesar kedua setelah pecahan ember. Hal ini dikarenakan masyarakat kurang memperhatikan kebersihan vas bunga yang mereka miliki serta tidak pernah melakukan pengecekan pada alas vas bunga dan air yang ada di dalam vas. Air sebagai media tumbuh tanaman hanya ditambahkan ke dalam vas dan tidak pernah diganti. Selain itu, tanaman adalah salah satu tempat istirahat yang disukai nyamuk sehingga vas bunga memiliki potensi besar untuk menjadi tempat berkembangbiak nyamuk.

Berdasarkan hasil uji statistic diperoleh nilai $\mathrm{P}$ value $=0.000$ (P value $<0.05)$ maka dapat disimpulkan bahwa terdapat hubungan yang bermakna antara jenis TPA lainnya dengan keberadaan jentik di kelurahan Penajam Kecamatan Penajam Tahun 2010.

Menurut Ginanjar [9], Nyamuk Aedes aegypti sangat suka tinggal dan berkembangbiak di genangan air bersih yang tidak terkontak langsung dengan tanah. 
Vektor penyebab DBD ini diketahui banyak bertelur di genangan air yang terdapat pada sisa-sisa kaleng bekas, ban bekas, dan sebagainya.

Jenis TPA Alami yang paling disukai nyamuk Aedes aegypti sebagai tempat perindukan adalah lubang pohon sebesar $26.1 \%$, potongan bambu sebesar $18.8 \%$, tempurung kelapa sebesar $15.4 \%$, pelepah daun $2.8 \%$ dan kulit kerang sebesar $0 \%$.

Hasil penelitian menunjukkan bahwa lubang pohon merupakan tempat yang sangat disukai oleh nyamuk Aedes aegypti untuk berkembang biak. Hal ini dapat terjadi karena lubang pohon merupakan wadah yang kurang mendapat perhatian dari manusia sehingga pada saat program PSN dilakukan wadah ini tidak tersentuh, disamping itu wadah ini dapat menampung air relatif lama.

Berdasarkan hasil uji statistic diperoleh nilai $\mathrm{P}$ value $=0.002(\mathrm{P}$ value $<0.05)$ maka dapat disimpulkan bahwa terdapat hubungan yang bermakna antara jenis TPA alami dengan keberadaan jentik di kelurahan Penajam Kecamatan Penajam Tahun 2010.
Berdasarkan Depkes RI [8], pada musim hujan, semakin banyak tempat penampungan alamiah yang terisi air hujan dan dapat digunakan sebagai tempat berkembangbiaknya nyamuk Aedes aegypti. Oleh karena itu, pada musim hujan, populasi Nyamuk Aedes aegypti meningkat. Bertambahnya populasi ini merupakan salah satu faktor yang menyebabkan peningkatan penularan virus Dengue yang pada akhirnya dapat meningkatkan angka penyakit Demam Berdarah Dengue.

\section{Kasus DBD}

Perhitungan nilai kepadatan Jentik (df) didapatkan dengan menggabungkan hasil perhitungan House Index (HI), Container Index (CI), serta Bretau Index (BI). Sementara daerah kasus dibagi menjadi 2 yaitu daerah kasus DBD tinggi dengan daerah kasus DBD rendah.

Untuk mengetahui hubungan antara Kasus DBD dengan Kepadatan Jentik, maka Tabel 2 diringkas dan dilakukan Uji lebih lanjut seperti terlihat pada Tabel 3 .

Tabel 2. Distribusi Kasus DBD Berdasarkan perhitungan Kepadatan Jentik

\begin{tabular}{|c|c|c|c|c|c|c|c|c|}
\hline \multirow{2}{*}{$\begin{array}{c}\text { Daerah Kasus } \\
\text { DBD }\end{array}$} & \multirow{2}{*}{ RT } & \multirow{2}{*}{ Diperiksa } & \multicolumn{2}{|c|}{ Jentik } & \multirow{2}{*}{$\mathrm{HI}$} & \multirow{2}{*}{ CI } & \multirow{2}{*}{$\mathrm{BI}$} & \multirow{2}{*}{ Df } \\
\hline & & & ada & Tidak & & & & \\
\hline \multirow{5}{*}{ Tinggi } & 1 & $\begin{array}{c}\text { Rumah } \\
\text { Konteiner }\end{array}$ & $\begin{array}{c}7 \\
25\end{array}$ & $\begin{array}{c}3 \\
117\end{array}$ & 70 & 17.61 & 250 & $\begin{array}{c}7.33 \\
\text { (tinggi) }\end{array}$ \\
\hline & \multirow{2}{*}{7} & Rumah & 10 & 0 & \multirow{2}{*}{100} & \multirow{2}{*}{34.16} & \multirow{2}{*}{550} & 8.67 \\
\hline & & Konteiner & 55 & 106 & & & & (tinggi) \\
\hline & \multirow{2}{*}{22} & Rumah & 8 & 2 & \multirow{2}{*}{80} & \multirow{2}{*}{16.51} & \multirow{2}{*}{180} & 7.33 \\
\hline & & Konteiner & 18 & 91 & & & & (tinggi) \\
\hline \multirow{4}{*}{ Rendah } & 4 & $\begin{array}{l}\text { Rumah } \\
\text { Konteiner }\end{array}$ & $\begin{array}{c}5 \\
14\end{array}$ & $\begin{array}{c}5 \\
126\end{array}$ & 50 & 10 & 140 & $\begin{array}{c}6.3 \\
\text { (tinggi) }\end{array}$ \\
\hline & \multirow[b]{2}{*}{11} & Rumah & 6 & 4 & \multirow[b]{2}{*}{60} & \multirow{2}{*}{12.69} & \multirow{2}{*}{170} & 6.67 \\
\hline & & Konteiner & 17 & 117 & & & & (tinggi) \\
\hline & 16 & $\begin{array}{l}\text { Rumah } \\
\text { Konteiner }\end{array}$ & $\begin{array}{l}4 \\
5\end{array}$ & $\begin{array}{c}6 \\
125\end{array}$ & 40 & 3.85 & 50 & $\begin{array}{c}4.67 \\
\text { (sedang) }\end{array}$ \\
\hline
\end{tabular}


Hubungan Antara Tempat Perindukan Nyamuk Aedes Aegypti Dengan Kasus Demam Berdarah Dengue di Kelurahan Penajam Kecamatan Penajam Kabupaten Penajam Paser Utara

Tabel 3. Distribusi Kasus DBD berdasarkan Kepadatan Jentik

\begin{tabular}{|c|c|c|c|c|c|c|}
\hline \multirow{3}{*}{ Kepadatan Jentik (df) } & \multicolumn{4}{|c|}{ Daerah kasus DBD } & \multirow{3}{*}{$\mathrm{N}$} & \multirow{3}{*}{$P$ value } \\
\hline & \multicolumn{2}{|c|}{ Tinggi } & \multicolumn{2}{|c|}{ Rendah } & & \\
\hline & $\mathrm{n}$ & $\%$ & $\mathrm{n}$ & $\%$ & & \\
\hline Tinggi & 3 & 60.0 & 2 & 40.0 & 5 & \multirow{3}{*}{1.000} \\
\hline Sedang & 0 & 0 & 1 & 100 & 1 & \\
\hline Jumlah & 3 & & 3 & & 6 & \\
\hline
\end{tabular}

Dari hasil penelitian tentang ketiga jenis tempat perindukan vektor Aedes aegypti (TPA, TPA Lainnya dan TPA Alami) yang dihitung berdasarkan HI, CI dan BI diperoleh angka kepadatan jentik (DF) paling tinggi yaitu 8.67 (df tinggi) terdapat pada RT 7, kemudian RT 22 dengan df 7.67 (df tinggi) dan RT 1 dengan df 7.3 (df tinggi) yang juga berada pada daerah kasus DBD tinggi. Sementara angka kepadatan jentik pada daerah kasus DBD rendah lebih kecil dibandingkan dengan daerah kasus DBD tinggi, yaitu df 6.67 (df tinggi) untuk RT 11, df 6.3 (df tinggi) untuk RT 4 dan df 5 (df sedang) untutk RT 16.

Sementara terdapat 2 RT yang berada pada daerah kasus DBD rendah namun memiliki angka densitas figure yang tinggi, yaitu RT 4 dan RT 11. Hal ini dapat terjadi karena data penderita DBD untuk menentukan daerah kasus DBD diambil dari bulan Januari - Juli di tahun 2010 dan penelitian dilakukan pada bulan November - Desember di tahun 2010. Selain itu, jarak dari satu RT ke RT yang lain relatif dekat dan jarak terbang nyamuk Aedes Aegypti kurang lebih 100 m. Sehingga tidak tertutup kemungkinan bahwa nyamuk Aedes Aegypti yang berada di RT yang dekat dengan RT 4 dan RT 11 terbang dan meletakkan telurnya di lingkungan RT dengan kasus DBD rendah setelah menghisap darah.

Sementara, berdasarkan hasil uji statistic diperoleh nilai $\mathrm{P}$ value $=1.00(\mathrm{P}$ value $>$ 0.05) maka dapat disimpulkan bahwa tidak terdapat hubungan yang bermakna antara kepadatan jentik pada TPA lainnya dengan kasus DBD di kelurahan Penajam Kecamatan Penajam Tahun 2010.

Hal ini kemungkinan terjadi karena besar sampel pada penelitian ini relatif kecil. Namun apabila besar sampel diperbesar dan daerah penelitian diperluas maka akan lebih nampak kepadatan vektor memiliki peran dalam terjadinya kasus DBD [2].

\section{KESIMPULAN DAN SARAN}

Kesimpulan dari penelitian ini adalah Ada hubungan antara Jenis Bahan TPA dengan keberadaan jentik dengan $\mathrm{p}=0.000(\mathrm{p}<0.05)$, ada hubungan antara keberadaan tutup TPA dengan keberadaan jentik dengan $\mathrm{p}=0.000$ $(\mathrm{p}<0.05)$, ada hubungan antara kebersihan TPA dengan keberadaan jentik dengan $\mathrm{p}=0.045 \quad(\mathrm{p}<0.05)$, Ada hubungan antara Jenis TPA Lainnya dengan Keberadaan Jentik $p=0.000 \quad(p<0.05)$, ada hubungan antara Jenis TPA Alami dengan Keberadaan Jentik $\mathrm{p}=0.002 \quad(\mathrm{p}<0.05)$, dan tidak ada hubungan antara Kepadatan Jentik dengan Kasus Demam Berdarah Dengue $\mathrm{p}=1.000$ $(\mathrm{p}>0.05)$.

Adapun saran yang dapat diberikan adalah agar masyarakat lebih banyak mempergunakan TPA berbahan Pelastik dan Porselen dan lebih memaksimalkan kegiatan 3M yaitu Menguras Tempat Penampungan Air, Menutup Rapat Tempat Penampungan Air, dan Mengubur Barang Bekas. Kepada pemerintah agar dapat mengoptimalkan kegiatan membersihkan lingkungan, salah satunya dengan mengaktifkan kembali 
Hubungan Antara Tempat Perindukan Nyamuk Aedes Aegypti Dengan Kasus Demam Berdarah Dengue di Kelurahan Penajam Kecamatan Penajam Kabupaten Penajam Paser Utara

gerakan Jumat Bersih serta meningkatkan suplay air bersih kepada masyarakat.

\section{DAFTAR PUSTAKA}

1. Anonim. 2009, Interaksi Edisi 5: Majalah Informasi dan Referensi Promosi Kesehatan; Jakarta.

2. Anonim. 2009, Interaksi Edisi 6: Majalah Informasi dan Referensi Promosi Kesehatan; Jakarta.

3. Apriliani, F.B. 2008, Hubungan Antara Tingkat Pengetahuan Kepala Keluarga Tentang Pencegahan Demam Berdarah Dengue (DBD) Dengan Container Index Di Desa Gondang Tani Kebupaten Sragen Tahun 2008. Surakarta: Universitas Muhammadiyah Surakarta. Online: diakses pada tanggal 20 April 2010. www.journal.ums.ac.id/J410040023

4. Anonim. 2009, Profil Dinas Kesehatan Provinsi Kalimantan Timur; Samarinda: Dinas Kesehatan Provinsi Kalimantan Timur.
5. Anonim. 2010, Profil Dinas Kelurahan Penajam. Penajam: Kelurahan Penajam Kabupaten PPU.

6. Nugroho, F.S. 2009, Faktor-Faktor Yang Berhubungan Dengan Keberadaan Jentik Aedes Aegypti Di Rw IV Desa Ketitang Kecamatan Nogosari Kabupaten Boyolali. Online: diakses pada tanggal 20 April 2010 www.journal.ums.ac.id/J410050002

7. Heldi, dkk. 2007, Kajian Tempat Perindukan Nyamuk di Kabupaten Bantul Yogyakarta. Online: diakses pada tanggal 20 April 2010 www.btkljogja.or.id

8. Depkes RI. 2003, Standar Pengawasan Program Bidang Kesehatan: Pemberantasan Demam Berdarah Dengue (DBD); Jakarta: Inspektorat Jenderal Departemen Kesehatan RI.

9. Ginanjar, G. 2008, Apa yang Dokter Anda Tidak Katakan tentang Demam Berdarah; Yogyakarta: B- First. 